
УДК 616-092.9

DOI 10.11603/1811-2471.2020.v.i3.11594

\title{
ВПЛИВ ПЕПТИДОГЛІКАНУ ЗОЛОТИСТОГО СТАФІЛОКОКА НА СПОНТАННУ СКОРОТЛИВУ АКТИВНІСТЬ МІОМЕТРІЯ ВАГІТНИХ ЩУРІВ
}

\author{
๑л. С. Насібян, І. Б. Філіпов, я. М. Шуба \\ Інститут фізіології імені О. О. Богомольця Національної академії наук України, Київ
}

РЕЗЮМЕ. Пептидоглікан Золотистого стафілокока - структурний елемент бактеріальної клітинної стінки, який вивільнюється протягом життєдіяльності мікроорганізму та розноситься кровотоком по організму. Осідаючи на тропних клітинах він реалізує патогенні та імуногенні властивості. Золотистий стафілокок досить часто висівається із сечостатевої системи жінок. Відомо, що взаємодія пептидоглікану з ендотеліальними та децидуальними клітинами матки під час вагітності ініціює такі ускладнення, як прееклампсія, стимуляція скоротливості активності матки, передчасне переривання вагітності. Однак досі достеменно не вивчені механізми дії пептидоглікану на міометрій.

Мета - визначити, чи впливає пептидоглікан на спонтанну скоротливість міометрія вагітних щурів за умов відсутності ендометрія, вивчити характер спонтанних скорочень міометрія вагітних щурів під дією пептидоглікану та механізми виявлених ефектів.

Матеріал і методи. Досліди проводили на гладеньком'язових смужках міометрія вагітних щурів лінії Вістар. Скоротливість міометрія вивчали методом тензометрії.

Результати. Результати експериментів показали, що, пептидоглікан модулює всі основні параметри спонтанних маткових скорочень за умов відсутності ендометрія. Він збільшував амплітуду та тривалість скорочень у середньому на 18,5 \% та 16 \%, відповідно. Водночас частота спонтанних скорочень зменшилась у середньому на 10,5 \%. Ряд параметрів скорочень міометрія свідчить про збільшення їх інтенсивності під дією пептидоглікану. Крім того, змінювалось співвідношення фаз скорочень міометрія: під дією пептидоглікану спонтанні скорочення міометрія мали відносно коротку, але високоамплітудну фазу скорочення, досить тривалий тонічний компонент та повільне розслаблення. Вказані фази скорочення міометрія на тлі дії пептидоглікану збільшились у середньому на 11,26 \%, 69,23 \% та 44,34 \% відповідно. На тлі блокаторів потенціал керованих кальцієвих каналів L-типу та ІП -рецепторів пептидоглікан не стимулював скорочення міометрія.

Висновки. Пептидоглікан має стимулювальну дію на спонтанну скоротливість міометрія шляхом впливу безпосередньо на міометрій. Модулювальний вплив пептидоглікану на скоротливість міометрія вагітних щурів пов'язаний зі збільшенням внутрішньоклітинного рівня кальцію в гладеньких міоцитах матки, що досягається завдяки посиленню трансмембранного входу кальцію та вивільненню із саркоплазматичного ретикулуму.

КлючовІ словА: міометрій; пептидоглікан; золотистий стафілокок; внутрішньоклітинний кальцій; скорочення міометрія.

Вступ. Золотистий стафілокок, що колонізує переважно шкіру, носову порожнину та шлунково-кишковий тракт, спричиняючи численні захворювання, $\epsilon$ також найпоширенішим мікроорганізмом у жіночому та чоловічому генітальних трактах [1-3]. Під час вагітності він викликає ускладнення хоріоамніонітом, посилення маткової скоротливості і, як наслідок, передчасні пологи [4].

Одним із факторів патогенності Золотистого стафілокока, ефект яких реалізується непрямим шляхом, часто мляво, безсимптомно та протягом тривалого часу, $\epsilon$ структурний компонент його стінки - пептидоглікан. Під час росту, ділення або руйнування мікроорганізму пептидоглікан потрапляє в кров, розноситься по організму, осідає на тропних клітинах та з часом ініціює патологічні процеси [5]. Було показано, що персистенція пептидоглікану в жіночому генітальному тракті призводить до порушення імплантації плідного яйця, а під час вагітності пептидоглікан залучений до розвитку прееклампсії $[6,7]$. Крім того, відомо, що під дією пептидоглікану відбувається стимуляція скоротливості вагітного міометрія як відповідь на дію прозапальних цитокінів, що секретуються імунокомпетентними клітинами ендометрія та децидуальної тканини [8].

Мета - визначити, яким саме чином змінюються параметри спонтанних скорочень вагітного міометрія під дією пептидоглікану та за яким механізмом такі зміни відбуваються.

Матеріал і методи дослідження. Експерименти проводили на смужках гладеньких м'язів десяти вагітних щурів у терміні гестації 8-11 днів при дотримуванні положень Директиви $\in C$ 2010/63/EU «СТосовно захисту тварин, що використовуються у наукових цілях» і вказівок інститутського біотичного комітету.

Скоротливу активність міометрія досліджували методом тензометрії в ізометричному режимі. Смужки поміщали в проточну камеру з одним кінцем зафіксованим нерухомо, а другим - прикріпленим до ємнісного датчика сили з базовим навантаженням 3 мН. Запис скоротливої активності здій- 
Огляди літератури, оригінальні дослідження, погляд на проблему, випадок з практики, короткі повідомлення снюваличерез аналогово-цифровий перетворювач на комп'ютер.

Усіх дослідних тварин анестезували ефіром та декапітували. Роги матки швидко видаляли і поміщали в нагрітий до $37^{\circ} \mathrm{C}$ оксигенований $(95 \%$ $\mathrm{O}_{2}$ і $5 \% \mathrm{CO}_{2}$ ) розчин Кребса: (ммоль/л): $\mathrm{NaCl} 120,4$; $\mathrm{KCl} 5,9 ; \mathrm{CaCl}_{2} 1,8 ; \mathrm{MgCl}_{2} 1,2 ; \mathrm{NaH}_{2} \mathrm{PO}_{4} 1,2 ; \mathrm{NaHCO}_{3}$ 15,5; глюкоза 11,5 (pH 7,4).

Роги матки розрізали вздовж, очищали від сполучної тканини та ендометрія, і нарізали повздовжні смужки довжиною 0,7-1,0 см і шириною 0,2-0,3 см. Смужки поміщали в проточну камеру, з одним кінцем зафіксованим нерухомо, а другим прикріпленим до ємнісного датчика сили з базовим навантаженням 3 мН. Запис скоротливої активності здійснювали через аналогово-цифровий перетворювач на комп'ютер.

Про характер скоротливої діяльності гладеньких м'язів матки й впливу на неї пептидоглікану судили за наступними параметрами: середньою частотою та амплітудою скорочень протягом 10 хв; площею під кривою скорочень, середньою тривалістю скорочень та пауз між ними; тривалістю маткового циклу (період часу від початку одного скорочення до початку наступного); індексом активності скорочень (відношення тривалості скорочень до тривалості пауз між ними); коефіцієнтом асиметрії (відношення тривалості систоли до тривалості діастоли скорочення), скоротливою активністю матки в Олександрійських одиницях (OU) (добуток середньої амплітуди скорочень в мН, середньої тривалості скорочень в хв та частоти скорочень за 10 хв [9]); максимальною швидкістю скорочення $\left(+\mathrm{dF} / \mathrm{dt}_{\text {max }}\right)$ - позитивний пік першої похідної скорочення, що характеризує максимальне збільшенням внутрішньоклітинного рівня кальцію в гладеньком'язових клітинах та фосфорилювання легких ланцюгів міозину; максимальною швидкістю розслаблення (-dF/dt $\left.{ }_{\max }\right)$ - негативний пік першої похідної скорочення. Характеризує максимальну деактивацію кальцієвих каналів, що $є$ наслідком припинення потенціалу дії в ГМК міометрія та зниження внутрішньоклітинного рівня кальцію; час активного скорочення (T, с) - час активного скорочення (проміжок часу між максимальними величинами +dF/dtmax та -dF/dtmax), що характеризує тривалість активного стану кальцієвих каналів мембрани гладеньком'язових клітин міометрія [10]; приріст швидкості напруги скорочення (відношення максимальної швидкості скорочення на тлі досліджуваної речовини до цієї ж величині в контролі); приріст швидкості напруги розслаблення (відношення максимальної швидкості розслаблення на тлі досліджуваної речовини до цієї ж величині в контролі) [11]; тривалість систоли скорочень (відстань від початку наростання напрустоли (відстань від початку швидкого розслаблення до досягнення кривої рівня базового тонусу); тривалість тонічного компонента скорочення.

Усі досліджувані речовини були від фірми «Sigma-Aldrich» (США). Пептидоглікан розводили в 0,9 \% розчину $\mathrm{NaCl}$ в концентрації 2 мг/мл і додавали до розчину Кребса в субмаксимальній концентрації 10-3 мг/мл [9]. Використовували такі реактиви: ніфедипін - блокатор потенціалзалежних кальцієвих каналів L-типу розводили в базовій концентрації в DMS 20 мМоль/л і додавали до розчину Кребса в концентрації 1 мкМоль/л; 2-АРВ (2-аміноетоксидифенілборат) - блокатор інозитолтрифосфатних рецепторів розводили в базовій концентрації в DMS 20 мМоль/л і додавали до розчину Кребса в концентрації 30 мкМоль/л,

Аналіз даних, статистична обробка результатів експериментів та їхнє графічне представлення здійснювалась за допомогою програмного забезпечення Origin 8.5. Для кожної серії експериментів визначали середні значення даних, які наводили у вигляді середнєџстандартна похибка середнього з позначенням числа смужок «п», на яких вони отримані. Статистичне порівняння контрольних значень параметрів і значень під впливом досліджуваних речовин проводили за допомогою парного Т-тесту Стьюдента, а між групами - за допомогою однофакторного дисперсійного аналізу ANOVO з поправкою Бенферроні.

Результати й обговорення. Смужка міометрія вагітного щура, очищена від ендометрія, спонтанно скорочувалась. Близько 30-40 \% відсотків спонтанних скорочень гладеньком'язових смужок міометрія були комбінованими, тобто в період від початку напруження м'язової смужки до досягнення базального рівня на записі скорочення спостерігається декілька (2 або більше) піків (рис. 1, А). На тлі регулярних спонтанних скорочень міометрія ми аплікували пептидоглікан. Співвідношення комбінованих та звичайних скорочень не змінилось. При обчисленні амплітуди комбінованих скорочень ми враховували значення найвищого піку. Тривалість скорочення обчислювали з моменту його початку і до розслаблення до рівня базального тонусу, незалежно від кількості піків комбінованих скорочень. Під дією пептидоглікану амплітуда та тривалість спонтанних скорочень міометрія збільшились, а частота - навпаки, зменшилась (рис. 1). Як видно з рисунка 2, площа під кривою скорочення під дією пептидоглікану збільшилась за рахунок амплітуди та тривалості скорочень.

у більшості смужок міометрія від вагітних щурів на тлі дії пептидоглікану зменшувався також базальний тонус, в середньому на 1,8 \% $0,65 \%$ від середньої амплітуди спонтанних скорочень. 

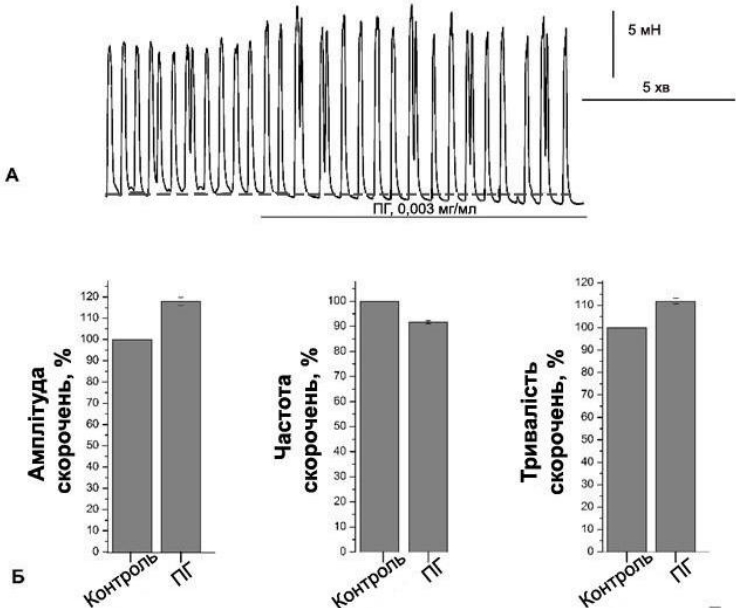

Рис. 1. Типовий запис, що демонструє дію пептидоглікану (ПГ) на скорочення міометрія вагітних щурів: А - ПГ збільшує амплітуду та тривалість спонтанних скорочень міометрія, але дещо знижує базальний тонус; Б - діаграми статистично узагальнених даних змін тривалості, частоти та амплітуди скорочень під дією ПГ (10-3 мг/мл) відносно контролю, прийнятого за $100 \%$; пунктирна лінія під кривою спонтанного скорочення базальний тонус; $n=10, p \leq 0,05$.

3більшення амплітуди та тривалості скорочень під впливом пептидоглікану призводило до збільшення площі під кривою скорочення на $36 \% \pm 2,36 \%$ в відносно контролю (рис. 2).

Під дією пептидоглікану змінилось також співвідношення тривалості фаз скорочення. Тривалість систоли скорочення збільшилась на 11,26 \% 1,68 \%, а тривалість діастоли - на 44,34 \% 1,2 \%. Тривалість тонічного компонента на тлі дії пептидоглікану збільшилась на 69,23 \% 1,45 \% відносно контролю. Як видно з рисунків 2 та 3, пептидоглікан викликає подовження тривалості всіх фаз м'язового скорочення. Тривалість пауз між скоро-

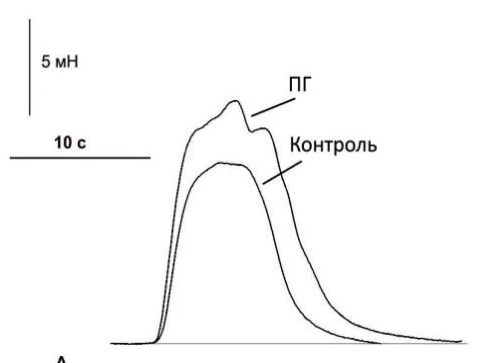

A

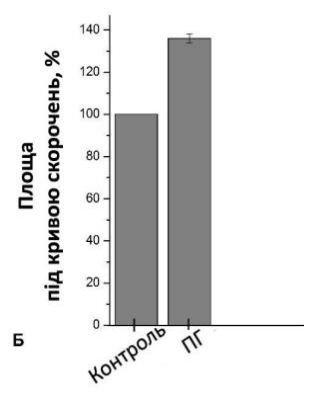

Рис. 2. А - типовий запис поодинокого спонтанного скорочення смужки міометрія вагітних щурів у контролі та під дією пептидоглікану (ПГ), що демонструє зміну площі під кривою скорочення за рахунок зростання амплітуди та тривалості; Б - діаграма статистично узагальнених даних змін площі під кривою під дією пептидоглікану (103 мг/мл) та в контролі, прийнятого за $100 \%$; n=10. ченнями під дією пептидоглікану збільшилась на 43,2 \% \$2,245 \% відносно контролю, що обумовлює зниження частоти скорочень більшою мірою, ніж збільшення їхньої тривалості. Аплікація пептидоглікану спричинила збільшення тривалості маткового циклу на 19,85 \% 1,27 \% відносно контролю, індекс активності скорочень зменшився на 3,54 \% (статистично недостовірно), а скоротлива активність міометрія вагітних щурів, виражена в Олександрійських одиницях, збільшилась на 56,8 \% 2,56 \% (табл. 1). Коефіцієнт асиметрії на тлі дії пептидоглікану зменшився на 23,88ะ0,56 \%.

Як видно з рисунка 3, пептидоглікан спричинив збільшення швидкості скорочення на 31 \%. Можна сказати, що на тлі пептидоглікану ініціація скорочення гладеньком'язової смужки відбувається більш різко. А от максимальна швидкість розслаблення скорочення на тлі дії пептидоглікану та в контролі майже однакова. Щоправда, досягається така швидкість, порівняно з контролем, дещо пізніше. Величина Т, тобто час активного скорочення, збільшилась на 25 \% (рис. 3).

Приріст швидкості досягнення максимуму скорочення, тобто відношення максимальної швидкості скорочення на тлі пептидоглікану до цієї ж величині в контролі, більше одиниці і складає 1,3. Натомість приріст швидкості досягнення максимуму розслаблення дорівнює 1,0. Отже, перший параметр більший за другий. А це свідчить [12] про позитивний інотропний ефект пептидоглікану на міометрій, що пов'язаний з активацією входу кальцію в міоплазму через сарколему та вивільненням його із саркоплазматичного ретикулуму. Оскільки приріст швидкості досягнення максимуму скоро-
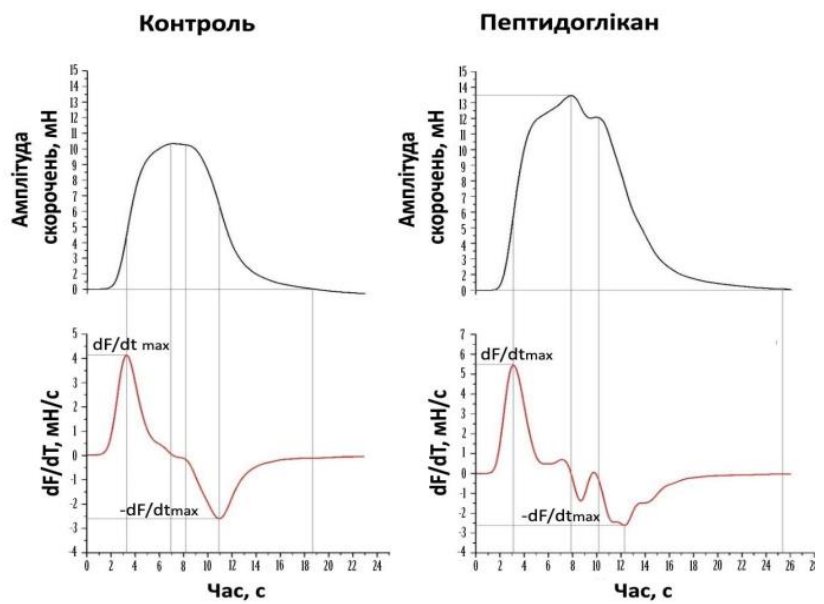

Рис. 3. Зміни амплітудно-кінетичних параметрів поодинокого спонтанного скорочення смужки вагітної матки під дією пептидоглікану. Контроль. Верхній графік - типовий запис поодинокого скорочення в контролі та на тлі пептидоглікану; на нижньому графіку - швидкості скорочення та розслаблення в контролі та на тлі пептидоглікану; $n=10, p \leq 0,005$. 
Огляди літератури, оригінальні дослідження, погляд на проблему, випадок з практики, короткі повідомлення

Таблиця 1. Зміни амплітудно-кінетичних параметрів спонтанних скорочень міометрія вагітних щурів

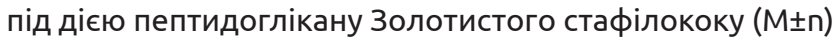

\begin{tabular}{|c|c|c|}
\hline Показники & Контроль & ПГ \\
\hline Тривалість систоли, с & $7,1 \pm 1,62$ & $7,9 \pm 0,365$ \\
\hline Тривалість діастоли, с & $10,6 \pm 0,38$ & $15,3 \pm 0,20 *$ \\
\hline Тривалість пауз між скороченнями, с & $8.36 \pm 1,76$ & $11.98 \pm 1,50 *$ \\
\hline Тривалість маткового циклу, с & $31,06 \pm 1,39$ & $37,63 \pm 1,27 *$ \\
\hline Індекс активності скорочень, ум. од. & $2,25 \pm 1,065$ & $2,171 \pm 0,653$ \\
\hline Скоротлива активність, Олександрійські одиниці & $32,2 \pm 11,89$ & $50,49 \pm 2,63 *$ \\
\hline Коефіцієнт асиметрії, ум. од. & $0,67 \pm 0,06$ & $0,51 \pm 0,07 *$ \\
\hline Приріст швидкості досягнення максимуму скорочення, ум. од & - & $1,309 \pm 0,203$ \\
\hline Приріст швидкості досягнення максимуму розслаблення, ум. од. & - & $1 \pm 0,207$ \\
\hline
\end{tabular}

Примітка. Наведені середні значення \pm SD, n=10 для кожного випадку; * - P<0,05 порівняно з контрольним значенням.

чення більше за приріст швидкості досягнення максимуму розслаблення, можна припустити, що підвищення рівня внутрішньоклітинного кальцію відбувається переважно шляхом трансмембранного кальцієвого входу.

Для того, щоб перевірити, чи індукує пептидоглікан вивільнення кальцію із саркоплазматичного ретикулуму під час вагітності, після встановлення регулярних спонтанних скорочень м'язової смужки ми замінили розчин Кребса номінально безкальцієвим розчином. Після того, як скорочення припинились, ми додали пептидоглікан до розчину Кребса без вільного $\mathrm{Ca}^{2+}$. Як результат, протягом 4-5 хвилин після початку аплікації пептидоглікану смужка двічі скоротилась і знову повністю розслабилась (рис. 4).

Для визначення впливу пептидоглікану на інозитолчутливе $\mathrm{Ca}^{2+}$-депо після встановлення регулярної спонтанної скоротливості міометрія вагітного щура аплікували блокатор $\mathrm{IP}_{3}$ рецепторів. На тлі дії 2-АРВ маткові скорочення припинились, а прикладання пептидоглікану після того не відновило скоротливість (рис. 5).

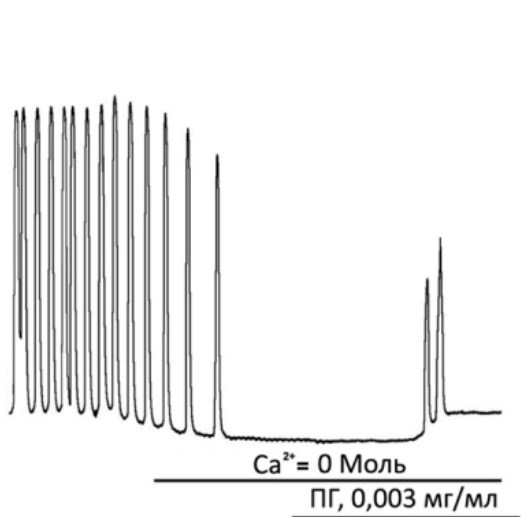

Рис. 4. Типовий запис, що демонструє здатність пептидоглікану викликати скорочення гладеньких м'язів міометрія вагітних щурів у безкальцієвому середовищі; ПГ- пептидоглікан; $\mathrm{n}=10, \mathrm{p} \leq 0,05$
Вхід Са ${ }^{2+}$ в ГМК міометрія відбувається головним чином через потенціал-керовані кальцієві канали L-типу [13]. Тож метою наступної серії експериментів було дослідження значення цих каналів в механізмі дії пептидоглікану.

При аплікації 1 мкМоль ніфедипіну на тлі стимульованих ПГ скорочень було виявлено пригнічення скоротливості міометрія до повного розслаблення (рис. 6).

Як видно з рисунка 6, блокування потенціалкерованих кальцієвих каналів L-типу призвело до повного припинення скорочень міометрія, попередньо посилених аплікацією пептидоглікану.

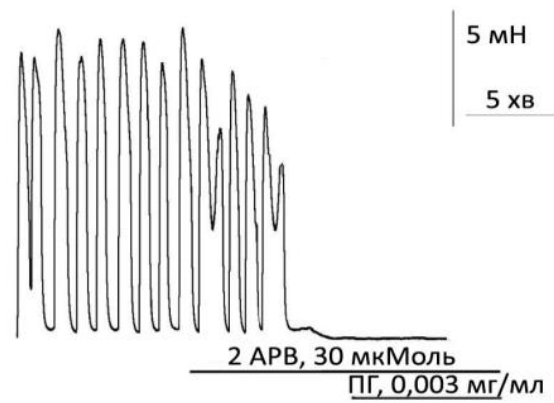

Рис. 5. Блокатор інозитолтрифосфатних рецепторів 2-АРВ пригнічує стимульовані пептидогліканом спонтанні скорочення міометрія вагітних щурів; ПГ - пептидоглікан; $n=10, p \leq 0,05$.

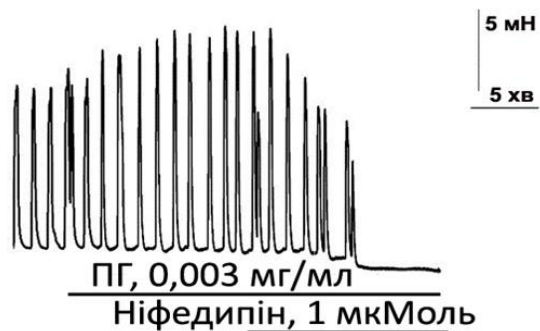

Рис. 6. Ніфедипін пригнічує стимульовані пептидогліканом спонтанні скорочення вагітного міометрія; ПГпептидоглікан; $n=10, P \leq 0,5$. 
Огляди літератури, оригінальні дослідження, погляд на

Висновок. Пептидоглікан модулює спонтанну скоротливість вагітного міометрія, впливаючи на всі основні параметри скорочень. Скорочення стають більш інтенсивними, збільшуються їхні амплітуда та тривалість, але частота знижується; під впливом пептидоглікану подовжуються всі фази спонтанних скорочень, але найбільше подовжуються тонічний компонент та фаза розслаблення; модуляція скоротливої активності міометрія пептидогліканом відбувається шляхом збільшення внутрішньоклітинного рівня кальцію в гладеньких міоцитах матки через збільшення транс-

\section{ЛІТЕРАТУРА}

1. The biology of bacterial peptidoglycans and their impact on host immunity and physiology / R. Wheeler, G. Chevalier, G. Eberl, I. Gomperts Boneca // Cell. Microbiol. - 2014. - Vol. 16 (7). - P. 1014-1023.

2. Ruiz N. Lipid flippases for bacterial peptidoglycan biosynthesis / N. Ruiz // Int. J. Med. Microbiol. - 2016. Vol. 13 (8). - P. 21-31.

3. Peptidoglycan perception--sensing bacteria by their common envelope structure / U. Bertsche, C. Mayer, F. Götz, A. A. Gust // Int. J. Med. Microbiol. - 2015. - Vol. 305 (2). P. 217-223.

4. Staphylococcus aureus infection of human gestational membranes induces bacterial biofilm formation and host production of cytokines / R. S. Doster, L. A. Kirk, L. M. Tetz [et al.] // J. Infect. Dis. - 2017. - Vol. 215 (4). - P. 653-657.

5. Human labour is associated with nuclear factorkappa $\mathrm{B}$ activity which mediates cyclo-oxygenase-2 expression and is involved with the 'functional progesterone withdrawal / V. C. Allport, D. Pieber, D. M. Slater [et al.] // Mol. Hum. Reprod. - 2001. - Vol. 7 (6). - P. 581-586.

6. Olson D. M. The role of prostaglandins in the initiation of parturition / D. M. Olson // Best Pract. Res. Clin. Obstet. Gynaecol. - 2003. - Vol. 17 (5). - P. 717-730.

7. Matthew T. Peptidoglycan: a critical activator of the mammalian immune system during infection and homeo-

\section{REFERENCES}

1. Wheeler, R., Chevalier, G., Eberl, G., \& Gomperts Boneca, I. (2014). The biology of bacterial peptidoglycans and their impact on host immunity and physiology. Cell. Microbiol., 16 (7), 1014-1023.

2. Ruiz, N. (2016). Lipid flippases for bacterial peptidoglycan biosynthesis. Int. J. Med. Microbiol., 13 (8), 21-31.

3. Bertsche, U., Mayer, C., Götz, F., \& Gust, A.A. (2015). Peptidoglycan perception-sensing bacteria by their common envelope structure. Int. J. Med. Microbiol., 305 (2), 217-223.

4. Doster, R.S., Kirk, L.A., Tetz, L.M., Rogers, L.M., Aronoff, D.M., \& Gaddy, J.A. (2017). Staphylococcus aureus infection of human gestational membranes induces bacterial biofilm formation and host production of cytokines. J. Infect. Dis., 215 (4), 653-657. роблему, випадок з практики, короткі повідомлення мембранного входу кальцію та вивільнення його із внутрішньоклітинного депо.

Перспективи подальших досліджень. Запропоноване нами пояснення механізму дії пептидоглікану Золотистого стафілококу на скоротливість міометрія доповнює наявні відомості, а значить, після продовження досліджень на рівні функціонування живого організму та клінічних досліджень, може розширити можливості контролю та корекції індукованих пептидогліканом аномалій маткової скоротливості під час вагітності.

stasis / T. Matthew, D. Sorbara, J. Philpott // Immunol. Rev. - 2011. - Vol. 243 (1). - P. 40-60.

8. Romero R. Intrauterine Infection, Preterm Labor, and Cytokines / R. Romero, O. Erez, J. Espinoza // Reprod. Sci.-2005.-Vol.12.-P.463-465. https://doi.org/10.1016/j. jsgi.2005.09.001.

9. El-Sahwi S. A new unit for evaluation of uterine activity / S. El-Sahwi, A. A. Gaafar, H. K. Toppozada // Am. J. Obstet. Gynecol. - 1967. - Vol. 98. - P. 900-903.

10. Phase-plot analysis of the oxytocin effect on human myometrial contractility / J. E. Gullam, A. M. Blanks, S. Thornton, A. Shmygol // Eur. J. Obstet. Gynecol. Reprod. Biol. - 2009. - Vol. 144 (1). - P. 20-24.

11. Пат. СССР № 1635133 А1. Способ определения кардиотропной активности вещей / Б. И. Лаптев, С. А. Богомаз, Е. М. Кулагин, С. А. Афанасьев, В. Д. Прокопьев. 1991 г.

12. Роль пептидогликана Staphylococcus aureus на сокращение гладких мышц / И. Б. Филиппов, Т. Л. Давыдовская, Л. С. Холодная, В. П. Посур // Нейрофизиология. -1996. - № 28 (1). - С. 30-36.

13. Csapo A. The evolution of uterine activity during human pregnancy / A. Csapo, J. Sauvage // Acta Obstet. Scand. - 2006. - Vol. 47 (2). - P. 181-212.

5. Allport, V.C., Pieber, D., Slater, D.M., Newton, R., White, J.O., \& Bennett, P.R. (2001). Human labour is associated with nuclear factor-kappa B activity which mediates cyclo-oxygenase-2 expression and is involved with the 'functional progesterone withdrawal. Mol. Hum. Reprod., 7 (6), 581-586.

6. Olson, D.M. (2003). The role of prostaglandins in the initiation of parturition. Best Pract. Res. Clin. Obstet. Gynaecol., 17 (5), 717-730.

7. Matthew, T., Sorbara, D., \& Philpott, J. (2011). Peptidoglycan: a critical activator of the mammalian immune system during infection and homeostasis. Immunol. Rev., 243 (1), 40-60.

8. Romero, R., Erez, O., \& Espinoza, J. (2005). Intrauterine infection, preterm labor, and cytokines. Reprod. Sci., 
Огляди літератури, оригінальні дослідження, погляд на проблему, випадок з практики, короткі повідомлення 12, 463-465. Retrieved from: https://doi.org/10.1016/j. jsgi.2005.09.001.

9. El-Sahwi, S., Gaafar, A.A., \& Toppozada, H.K. (1967). A new unit for evaluation of uterine activity. Am. J. Obstet. Gynecol., 98, 900-903.

10. Gullam, J.E., Blanks, A.M., Thornton, S., \& Shmygol, A. (2009). Phase-plot analysis of the oxytocin effect on human myometrial contractility. Eur. J. Obstet. Gynecol. Reprod. Biol., 144 (1), 20-24.

11. Laptev, B.I., Bogomaz, S.A., Kulagin, Ye.M., Afanasyev, S.A., Prokopyev, V.D. (1991). Sposob opredeleniya

kardiotropnoy activnosti veschestv. [Method for determining the cardiotropic activity of substances]. USSR Patent № 1635133 A1 [in Russian].

12. Philippov, I.B., Davidovskaya, T.,L., Kholodna, L.S., Posur, V.P. (1996). Rol peptidoglikana Staphylococcus aureus na sokrashcheniye gladkikh myshts [The role of Staphylococcus aureus peptidoglycan on the smooth muscle contractions]. Neyrophysiologia - Neurophysyology, 28 (1), 30-36 [in Russian].

13. Csapo, A., \& Sauvage, J. (2006). The evolution of uterine activity during human pregnancy. Acta Obstet. Scand., 47 (2), 181-212.

\title{
ВЛИЯНИЕ ПЕПТИДОГЛИКАНА ЗОЛОТИСТОГО СТАФИЛОКОККА НА СПОНТАННУЮ СОКРАТИТЕЛЬНУЮ АКТИВНОСТЬ МИОМЕТРИЯ БЕРЕМЕННЫХ КРЫС
}

\section{ФЛ. С. Насибян, И. Б. Филиппов, Я. М. Шуба}

\author{
Институт физиологии имени А. А. Богомольца Национальной академии наук Украины, Киев
}

РЕЗЮМЕ. Пептидогликан Золотистого стафилококка - структурный элемент бактериальной клеточной стенки, который высвобождается в течение жизнедеятельности микроорганизма и разносится кровью по организму. Оседая на тропных клетках, он реализует патогенные и иммуногенные свойства. Золотистый стафилококк достаточно часто высевается из мочеполовой системы женщин. Известно, что взаимодействие пептидогликана с эндотелиальными и децидуальными клетками матки во время беременности инициирует такие осложнения, как преэклампсия, стимуляция сократительной активности матки, преждевременное прерывание беременности. Однако до сих пор точно не изучены механизмы действия пептидогликана на миометрий.

Цель - определить, влияет ли пептидогликан на спонтанную сократимость миометрия беременных крыс в условиях отсутствия эндометрия, изучить характер спонтанных сокращений миометрия беременных крыс под действием пептидогликана и механизмы обнаруженных эффектов.

Материал и методы. Опыты проводили на гладкомышечных полосках миометрия беременных крыс линии Вистар. Сократимость миометрия изучали методом тензометрии.

Результаты. Результаты экспериментов показали, что пептидогликан модулирует все основные параметры спонтанных маточных сокращений при отсутствии эндометрия. Он увеличивал амплитуду и длительность сокращений в среднем на 18,5 \% и 16 \% соответственно. В то же время, частота спонтанных сокращений уменьшилась в среднем на 10,5 \%. Ряд параметров свидетельствовал об увеличении интенсивности сокращений миометрия под действием пептидогликана. Кроме того, менялось соотношение фаз сокращений: под действием пептидогликана спонтанные сокращения миометрия имели относительно короткую, но высокоамплитудную фазу сокращения, достаточно длительный тонический компонент и медленное расслабление. Указанные фазы сокращения миометрия на фоне действия пептидогликана увеличились в среднем на 11,26 \%, 69,23 \% и 44,34 \% соответственно. На фоне блокаторов потенциалзависимых кальциевых каналов L-типа и ИФ--рецепторов пептидогликан не стимулировал сокращение миометрия.

Выводы. Пептидогликан имеет стимулирующее действие на спонтанную сократительность миометрия путем воздействия непосредственно на миометрий. Модулирующее влияние пептидогликана на сократимость миометрия беременных крыс связана с увеличением внутриклеточного уровня кальция в гладких миоцитах матки, что достигается благодаря усилению трансмембранного входа кальция и его высвобождению из саркоплазматического ретикулума.

КЮЧЕВЫЕ СЛОВА: миометрий; пептидогликан; золотистый стафилококк; внутриклеточный кальций; сокращения миометрия.

\section{STAPHYLOCOCCUS AUREUS PAPTIDOGLYCAN'S EFFECT ON THE MYOMETRIAL SPONTANEOUS CONTRACTILITY OF PREGNANT RATS}

\section{OL. S. Nasibian, I. B. Philippov, Ya. M. Shuba \\ O. Bohomolets Institute of Physiology of the National Academy of Sciences of Ukraine}

SUMMARY. Peptidoglycan of Staphylococcus aureus is a structural element of the bacterial cell wall. It is released during the lifespan of bacterial cells and propagated by the bloodstream to the cells with tropism to it. In such tissues it is able to initiate some pathological processes. Staphylococcus aureus is often sown from the female genitourinary tract. It is known that the interaction of peptidoglycan with endothelial and decidual cells of the uterus during pregnancy initi- 
Огляди літератури, оригінальні дослідження, погляд на проблему, випадок з практики, короткі повідомлення ates such complications as preeclampsia, stimulation of uterine contractility, and preterm birth. However, the mechanisms of action of peptidoglycan on the myometrium have not yet been precisely studied.

The aim - to determine whether peptidoglycan affects the myometrial spontaneous contractility in pregnant rats when the endometrium is removed, to study the character of spontaneous myometrial contractions in pregnant rats under peptidoglycan and the mechanisms of the revealed effects.

Material and Methods. The experiments were conducted on myometrial smooth muscle strips of pregnant Wistar rats. The myometrial contractility was studied by tensometry method.

Results. Experimental results showed that peptidoglycan modulates all the main parameters of spontaneous uterine contractions in the absence of endometrium. It increased the amplitude and duration of contractions by an average of $18.5 \%$ and $16 \%$, respectively. At the same time, the frequency of spontaneous contractions decreased by an average of $10.5 \%$. A number of parameters indicated an increase in the intensity of myometrial contractions under peptidoglycan. In addition, the ratio of the contraction phases changed: under the action of peptidoglycan, myometrial spontaneous contractions had a relatively short but high-amplitude contraction phase, a rather long tonic component, and slow relaxation. The indicated phases of myometrial contractions under peptidoglycan increased by an average of $11.26 \%, 69.23 \%$ and $44.34 \%$, respectively. Under the blockers of L-type potential-gated calcium channels and $\mathrm{IP}_{3}$-receptors, peptidoglycan did not stimulate myometrial contractions.

Conclusions. The peptidoglycan has a stimulating effect on myometrial spontaneous contractility by acting directly on the myometrium. The modulating effect of peptidoglycan on myometrial contractility in pregnant rats is associated with an increase in the intracellular calcium level in smooth uterine myocytes, which is achieved due to an increase in the transmembrane calcium entry and its release from the sarcoplasmic reticulum.

KEY WORDS: myometrium; peptidoglycan; Staphylococcus aureus; intracellular calcium level; myometrial contractions.

Отримано 21.08.2020 